\title{
Eksplorasi dan Identifikasi Populasi Kopi Liberika (Coffea liberica) di Kecamatan Sukorejo, Kabupaten Kendal
}

\section{Exploration And Identification Of Liberika Coffee (Coffea Liberica) In Sukorejo, Kendal District}

\author{
Nafarain Haniefan, Panjisakti Basunanda*
}

\author{
Departemen Budidaya Pertanian, Fakultas Pertanian, Universitas Gadjah Mada \\ Jalan Flora No. 1, Bulaksumur, Sleman, Yogyakarta 55281, Indonesia. \\ *) Penulis untuk korespodensi E-mail: panjisakti@ugm.ac.id \\ Diajukan: 19 Maret 2019 /Diterima: 4 Februari 2022 /Dipublikasi: 28 Februari 2022
}

\begin{abstract}
Liberika coffee (Coffea liberica) is a type of coffee that is unique in taste and plant morphology. The type of liberika coffee in the community farms of the Kalibagor Village has a diverse character. This causes unoptimal production. Plant exploration and identification need to be done. So population distribution is based on its morphological character can be mapped. This research was carried out using quantitative descriptive methods. Observations were carried out on 40 accessions of liberica coffee plants and 5 accessions to robusta coffee as controls spread across farms belonging to farmers. Liberika coffee can be grouped based on the morphological character of leaf length, leaf width, leaf area, leaf shape, apex shape, fruit length, fruit width, fruit shape, discus shape, seed length, and seed width. Based on the morphological characters of 40 accessions of coffee plants which are thought to be liberica type coffee is completely different from Robusta coffee as a control. Cluster analysis divided 45 accessions of coffee plants which were observed into 5 groups with similarities above $65 \%$. The five coffee accession groups observed were spread randomly with the highest group variations in the gardens of Mr. Rosyid and Mr. Mudrik.
\end{abstract}

Keywords : coffee; germplasm exploration; liberica; rural resources.

\section{INTISARI}

Kopi liberika (Coffea liberica) adalah jenis kopi yang memiliki keunikan pada rasa maupun morfologi tanamannya. Jenis kopi liberika yang terdapat di kebun masyarakat Desa Kalibagor memiliki karakter yang beragam. Hal tersebut menyebabkan produksi yang kurang optimal. Eksplorasi dan identifikasi tanaman perlu dilakukan. Sehingga dapat dipetakan sebaran populasi berdasarkan karakter morfologinya. Penelitian ini dilaksanakan menggunakan metode deskriptif kuantitatif. Pengamatan dilakukan pada 40 aksesi tanaman kopi liberika dan 5 aksesi kopi robusta sebagai kontrol yang tersebar pada kebun milik petani. Kopi liberika dapat dikelompokkan berdasarkan karakter morfologi panjang daun, lebar daun, luas daun, bentuk daun, bentuk apex, panjang buah, lebar buah, bentuk buah, bentuk diskus, panjang biji, dan lebar biji. Berdasarkan karakter morfologi $\mathbf{4 0}$ aksesi tanaman kopi yang diduga kopi jenis liberika benar berbeda dengan kopi jenis robusta sebagai kontrol. Analisis gerombol (cluster) 
membagi 45 aksesi tanaman kopi yang diamati menjadi 5 kelompok dengan tingkat kemiripan diatas $65 \%$. Kelima kelompok aksesi kopi yang diamati tersebar secara acak dengan variasi kelompok tertinggi pada kebun milik Bapak Rosyid dan Bapak Mudrik.

Kata kunci : eksplorasi plasma nutfah; kopi; liberika; sumberdaya pedesaan.

\section{PENDAHULUAN}

Kopi (Coffea sp.) adalah spesies tanaman berbentuk pohon dan termasuk dalam famili Rubiaceae dan genus Coffea. Tanaman ini tumbuh tegak, bercabang dan dapat mencapai tinggi $12 \mathrm{~m}$. Tanaman kopi terdiri dari jenis Coffea arabica, Coffea robusta, dan Coffea liberica. Tanaman kopi merupakan komoditas ekspor dengan nilai ekonomis yang relatif tinggi di pasaran dunia, di samping merupakan salah satu komoditas unggulan yang dikembangkan di Indonesia. Sudah hampir tiga abad kopi diusahakan penanamannya di Indonesia untuk memenuhi kebutuhan konsumsi di dalam dan luar negeri.

Salah satu jenis kopi unggulan dari Desa Kalibogor, Kecamatan Sukorejo, Kabupaten Kendal adalah kopi liberika (Coffea liberica). Menurut pemilik kebun dan petani kopi setempat, kopi liberika di daerah tersebut sudah mulai ditanam sejak zaman kolonial belanda. Kopi tersebut memiliki cita rasa yang unik dan aroma khas seperti buah nangka, namun jenis kopi tersebut kurang diminati oleh petani untuk dibudidayakan karena memiliki produksi yang rendah. Beberapa pohon liberika dipangkas kemudian disambung dengan jenis kopi lain karena kopi liberika dianggap memiliki perakaran yang baik.
Pada dasarnya kegiatan utama pemuliaan tanaman meliputi tiga hal yaitu: 1 ) eksplorasi dan identifikasi, 2) seleksi, dan 3) evaluasi. Eksplorasi adalah suatu kegiatan yang bertujuan mengumpulkan dan mengkoleksi semua sumber keragaman genetik yang tersedia. Identifikasi merupakan suatu kegiatan karakterisasi semua sifat yang dimiliki atau yang terdapat pada sumber keragaman gen sebagai data base sebelum memulai rencana pemuliaan tanaman. Identifikasi dapat dilakukan melalui tiga cara: 1) identifikasi berdasarkan morfologi, 2) identifikasi berdasarkan sitologi, dan 3) identifikasi berdasarkan pola pita DNA (molekuler) (Jamsari, 2008).

Kopi Liberika memiliki ukuran yang lebih besar dibandingkan dengan jenis kopi lainnya. Bentuk biji membulat oval (panjang 0,83-1,10 cm, lebar $0,61 \mathrm{~cm}$ ), dengan rendemen rata-rata $9,03 \%$. Persentase biji normal berkisar $50-80 \%$. Kopi ini memiliki potensi produksi rata-rata $1,2 \mathrm{~kg}$ kopi bij/pohon, atau setara dengan 1,1 ton biji kopi untuk penanaman dengan populasi 9001.100 pohon/ha. Kopi Liberika menghendaki syarat tumbuh yang lebih mudah dibandingkan dengan jenis kopi yang lainnya. Kopi Liberika lebih mudah beradaptasi, dan dapat tumbuh di dataran rendah (<800 mdpl). Pada umumnya tanaman kopi menghendaki 
tanah yang lapisan atasnya dalam, gembur, subur, banyak mengandung humus, atau dengan kata lain tesktur tanah yang baik. Kemasaman tanah yang dibutuhkan tanaman kopi yaitu 5,5-5,6 (Budiman, 2012).

Luas Wilayah Desa Kalibogor, Kecamatan Sukorejo, Kabupaten Kendal termasuk daerah dataran tinggi dengan ketinggian $\pm 400 \mathrm{~s} / \mathrm{d} 1.200 \mathrm{~m}$ di atas permukaan air laut, curah hujan 2.600 $\mathrm{mm} /$ tahun, suhu rata-rata $23-26{ }^{\circ} \mathrm{C}$ dengan luas wilayah Desa Kalibogor secara keseluruhan 1.832,55m (183,255ha) dan berdasarkan penggunaannya dapat dilihat sebagai berikut:

1. Pertanian -Tanah Sawah 99 ha -Tanah tegal 40 ha

2. Tanah pekarangan/Bangunan 60,100 ha

3. Tanah lain-lain

4. Perkebunan Rakyat Jumlah 183,255 ha

Menurut Bernawi et al. (2002) karakterisasi adalah salah satu tahapan penting dalam suatu rangkaian kegiatan pemuliaan tanaman. Karakterisasi dilakukan pada karakter-karakter yang lebih mudah diwariskan, mudah diamati dan sedikit dipengaruhi oleh faktor lingkungan. Ekspresi karakter-karakter yang bersifat kuantitatif tidak mudah kelihatan dan terekam. Oleh karena itu karakterisasi terhadap karakterkarakter yang bersifat kualitatif penting dilakukan.

\section{BAHAN DAN METODE}

Penelitian ini dilaksanakan pada bulan Juli 2018-Agustus 2018 di Desa Kalibogor, Kecamatan Sukorejo, Kabupaten
Kendal, Provinsi Jawa Tengah. Alat yang digunakan dalam penelitian ini adalah kertas, penggaris, dan kamera digital. Sedangkan bahan yang digunakan adalah daun, dan buah dari tanaman sampel.

Penelitian ini dilaksanakan menggunakan metode deskriptif kuantitatif. Data diperoleh melalui karakterisasi in situ (tanaman yang terdapat pada habitat aslinya) pada tanaman kopi Liberika dengan cara mengamati langsung pada sampel tanaman kopi Liberika yang terdapat di beberapa lokasi kebun milik petani liberika yang tersebar di Desa Kalibagor, Kecamatan Sukorejo, Kabupaten Kendal. Teknik pengambilan sampel menggunakan Proportional stratified random sampling yaitu teknik pengambilan sampel dengan memperhatikan strata atau tingkatan proporsi sampel yang diambil pada tanaman. Pengamatan sampel dilakukan pada beberapa karakter morfologi tanaman kopi Liberika dengan berdasarkan panduan Descriptors for Coffee (International Plant Genetic Resources Institute, 1996).

Penelitian ini dilaksanakan dengan empat tahapan yaitu tahap awal, tahap kegiatan, tahap pengamatan, dan tahap akhir. Tahap awal penelitian ini, bertujuan mendapatkan data pendukung melalui wawancara kepada petani kopi Liberika dengan mengajukan beberapa pertanyaan seperti sumber bibit yang digunakan, kegiatan budidaya, dan informasi geografis. Tahap kegiatan dilakukan dengan cara pengumpulan data lapangan berupa sampel daun, buah, dan biji dari tanaman terpilih. 
Data tanaman terpilih diperoleh dengan mengamati karakter morfologi tanaman kopi Liberika. Pengamatan dilakukan dengan tahapan sebagai berikut: Menentukan tanaman sampel berupa tanaman kopi yang diduga liberika sebanyak 40 tanaman yang tersebar di beberapa kebun milik petani, memilih 5 tanaman kopi robusta yang digunakan sebagai tanaman pembanding, dan Mencatat lokasi dan morfologi tanaman terpilih. Tahap Pengamatan dilakukan pada 45 aksesi tanaman kopi yang terdiri dari 40 tanaman kopi yang diduga jenis liberika dan 5 tanaman kopi robusta yang tersebar di beberapa kebun milik petani kopi Desa Kalibagor, Kecamatan Sukorejo, Kabupaten Kendal.

Pengamatan terhadap aksesi kopi liberika terpilih secara kuantitatif dengan sampel berupa daun, buah, dan biji dengan 5 ulangan tiap aksesi. Sampel diukur menggunakan software Image $J$ dengan menganalisis gambar yang sebelumnya diambil menggunakan kamera digital. Parameter yang diamati dengan metode ini meliputi panjang daun, lebar luas daun, panjang buah, lebar buah, panjang biji, lebar biji. Pengamatan langsung secara visual meliputi parameter bentuk daun, bentuk ujung daun (apex), bentuk diskus, dan bentuk buah. Software GPS Google Maps digunakan untuk menentukan titik koordinat tanaman sampel.

Tahap akhir penelitian adalah pengelompokan data dari hasil pengamatan terhadap karakter buah dan biji kopi Liberika secara kualitatif dan kuantitatif, kemudian dilanjutkan dengan analisis data. PCA biplot dan analisis gerombol digunakan untuk melihat tingkat kekerabatan berdasarkan karakter morfologi dan membentuk kelompok-kelompok untuk mempermudah pemetaan sebaran populasi. Kelompok hasil analisis kemudian ditandai pada peta sesuai dengan koordinat yang tercatat menggunakan software Google Maps.

\section{HASIL DAN PEMBAHASAN}

Gambar biplot pada Gambar 1. menunjukkan aksesi kopi robusta memiliki nilai kuantitatif yang berbeda secara signifikan dengan nilai kuantitatif aksesi kopi liberika. Dapat dilihat letak titik aksesi kopi robusta bertolak belakang dengan parameter panjang daun, lebar daun, dan luas daun. Hal tersebut menunjukkan ukuran daun robusta yang lebih kecil dibandingkan ukuran kopi liberika. Adapun letak titik aksesi kopi liberika yang sejajar dengan garis parameter rasio daun menunjukkan bentuk daun yang cenderung memanjang.

Dendogram pada Gambar 2. digunakan untuk mengelompokkan aksesi berdasarkan kemiripan morfologi. Data yang dijadikan acuan adalah data kualitatif dengan parameter bentuk daun, bentuk apex (ujung daun), bentuk buah, dan bentuk diskus. Dari 45 aksesi dapat dikelompokkan menjadi 5 kelompok dengan tingkat kemiripan di atas $60 \%$. Anggota dari hasil pembagian kelompok tersebut yaitu, kelompok 1: budi5, budi4, kom1, budi3, kom6, ros3, ros5, mudrik3, dan kom7, kelompok 2: san6, san5, 


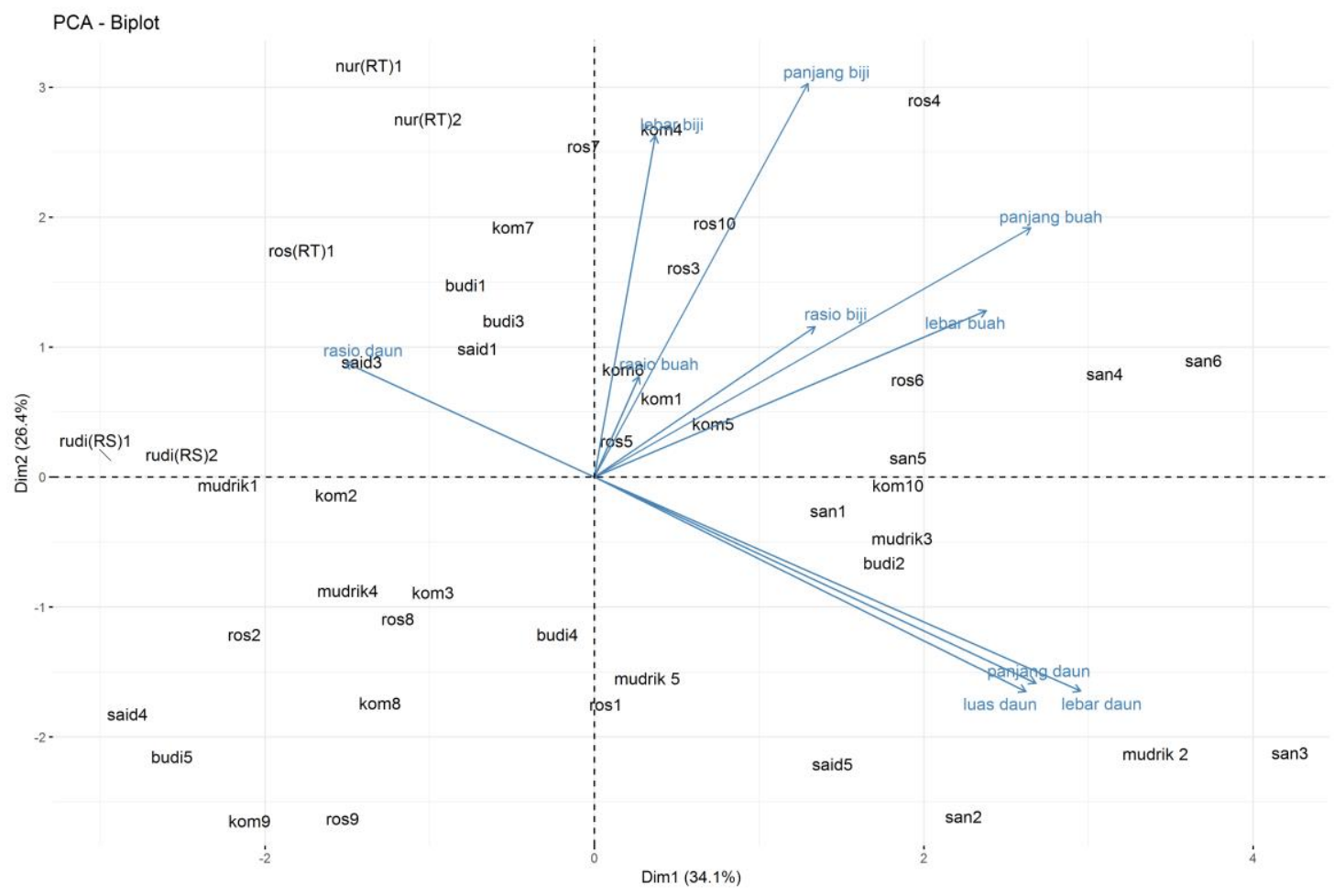

Gambar 1. Gambar biplot PC1 dan PC2 hasil analisis PCAdengan data kuantitatif pada 45 aksesi tanaman kopi

ros9, ros8, ros10, san3, budi2, mudrik5, dan kom2, kelompok 3: rudi(RS)2, rudi(RS)1, nur(RT)2, nur(RT)1, dan ros(RT)1, kelompok 4: kom9, kom3, said3, said4, budi1, mudrik2, san2, kom4, mudrik1, ros6, kom8, san4, kom10, san1, ros2, dan kom5, kelompok 5: said5, said1, ros7, mudrik4, dan ros4.

Sebaran aksesi anggota kelompok kopi liberika dan robusta tersebar secara acak di Desa Kalibagor, Kecamatan Sukorejo, Kabupaten Kendal. Terdapat 2 kebun dengan tingkat variasi kelompok yang tinggi yaitu kebun milik Bapak Rosyid (Ros) dan kebun milik Bapak Mudrik (Murdrik). Sesuai dengan hasil wawancara saat pengamatan, kebun kopi liberika milik Bapak Rosyid dan Bapak Mudrik adalah kebun kopi liberika yang paling tua. Narasumber menyebutkan bahwa bibit kopi berasal dari perkebunan kopi milik belanda yang saat ini lokasi perkebunan menjadi kebun milik PTPN IX. Bibit kopi liberika diberikan secara acak kepada masyarakat Desa Kalibagor yang saat itu bekerja di perkebunan kopi tersebut untuk kemudian ditanam.

Beberapa perkebunan kopi liberika saat ini sudah dilakukan sambung pucuk dengan kopi robusta dikarenakan kopi liberika dianggap tidak memiliki nilai ekonomi yang cukup baik. Produksi tanaman kopi liberika yang sedikit dan waktu panen yang tidak menentu menjadi alasan masyarakat melakukan sambung pucuk kopi liberika dengan kopi robusta varietas Tugusari (TS) ataupun Sumber Asin (SA). Hanya tersisa beberapa kebun yang masih ditanami kopi liberika yaitu kebun yang dijadikan lokasi penelitian. 


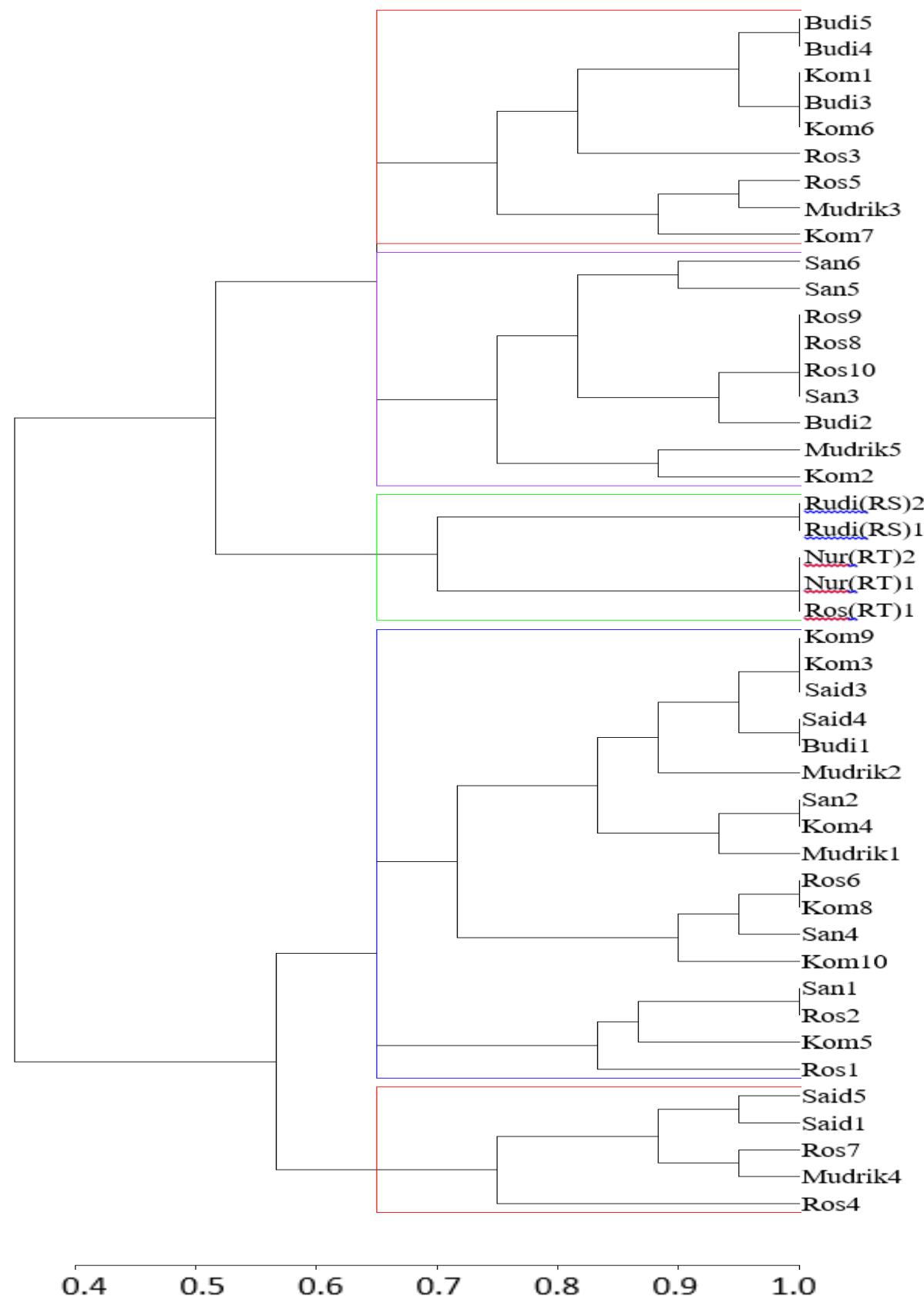

Gambar 2. Gambar dendogram hasil analisis klaster (gerombol) dengan menggunakan data kualitatif pada 45 aksesi tanaman kopi.

Kopi liberika bukan komoditas yang pemangkasan, ataupun perawatan lainnya. dijadikan mata pencaharian utama oleh Namun beberapa tahun terakhir muncul pemilik kebun. Salah satu alasan pemilik Badan Usaha Milik Desa (BUMDES) yang kebun kopi liberika masih membudidayakan mengangkat potensi daerah Desa Kalibagor kopi tersebut karena kurangnya minat pada yaitu tanaman kopi. Setelah melakukan budidaya tanaman kopi sehingga tanaman cupping beberapa kali, kopi liberika dari Desa tidak terurus, tidak dilakukan pemupukan, Kalibagor memiliki rasa yang sangat unik dan 


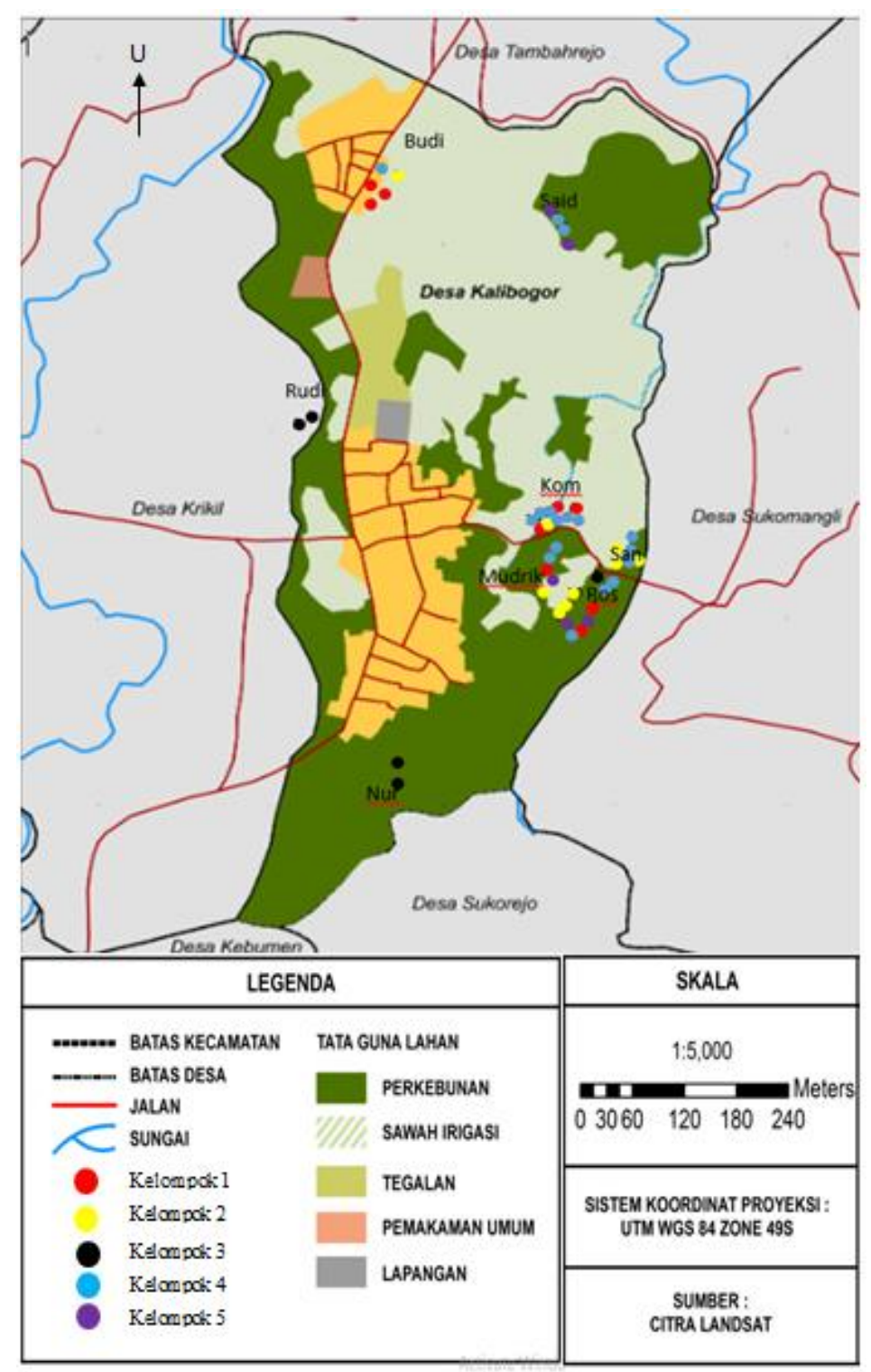

Gambar 3. Peta sebaran aksesi kopi liberika di Desa Kalibagor, Kecamatan Sukorejo, Kabupaten Kendal.

menarik banyak peminat. Hal tersebut pengamatan tersebut tidak bisa diambil mendorong pemilik kebun kembali lebih datanya. Perlu dilakukan penelitian lebih peduli dan mulai meremajakan kopi lanjut untuk dapat meningkatkan kesadaran liberikanya. pemilik kebun terhadap potensi kopi

Beberapa pengamatan singkat liberikanya. Terlebih untuk kepentingan menunjukkan ada keunikan seperti warna pelestarian plasma nutfah sifat-sifat tanaman buah, bentuk pohon, tekstur buah, dan kopi liberika yang unik dan bervariasi harus parameter pengamatan lainnya. Namun dijaga sehingga tidak hilang dan bahan keterbatasan waktu dan musim yang kurang genetiknya dapat berguna di kemudian hari. sesuai menyebabkan parameter 


\section{KESIMPULAN}

Berdasarkan karakter morfologi 40 aksesi tanaman kopi yang diduga kopi jenis liberika benar berbeda dengan kopi jenis robusta sebagai kontrol. Analisis gerombol (cluster) membagi 45 aksesi tanaman kopi yang diamati menjadi 5 kelompok dengan tingkat kemiripan di atas 65\%. Kelima kelompok aksesi kopi yang diamati tersebar secara acak dengan variasi kelompok tertinggi pada kebun Bapak Rosyid dan Bapak Mudrik.

\section{UCAPAN TERIMA KASIH}

Terimakasih diucapkan kepada masyarakat Desa Kalibagor dan BUMDES Bagormas yang telah bekerja sama dan mendukung kegiatan penelitian hingga selesai, semoga penelitian ini dapat bermanfaat.

\section{DAFTAR PUSTAKA}

Bernawie, N., Ajijah N., dan Rostiana, O. 2002. Karakterisasi Morfologi dan Mutu Adas (Feonim vulgare Mill). Buletin Penelitian Tanaman Rempah dan Obat 13(2):26.

Budiman, H. 2012. Prospek Tinggi Bertanam Kopi. Pustaka Baru Press. Yogyakarta.

International Plant Genetic Resources Institute. 1996. Descriptors for coffee (Coffea spp. and Psilanthus spp.). Roma(ITA): Testo Monografico.

Jamsari. 2008. Pengantar pemuliaan landasan genetis, biologis, dan molekuler. Penerbit UNRI Press. 